\title{
Assessment of Soft Tissue Changes by Cephalometry and Two- Dimensional Photogrammetry in Bilateral Sagittal Split Ramus Osteotomy Cases
}

\author{
Jan Rustemeyer ${ }^{1}$, Alice Martin ${ }^{1}$ \\ 'Department of Oral and Maxillofacial Surgery, Center Clinic Bremen, Medical School of the University of Göttingen, \\ Bremen, Germany.
}

\author{
Corresponding Author: \\ Jan Rustemeyer \\ Klinik für Mund-, Kiefer- und Gesichtschirurgie, Klinikum Bremen-Mitte \\ 28177 Bremen \\ Germany \\ Phone: 00494214972451 \\ Fax: 00494214972461 \\ E-mail: janrustem@gmx.de
}

\begin{abstract}
Objectives: We aimed to compare the standard methods of cephalometry and two-dimensional photogrammetry, to evaluate the reliability and accuracy of both methods.

Material and Methods: Twenty-six patients (mean age 25.5, standard deviation (SD) 5.2 years) with Class II relationship and 23 patients with Class III relationship (mean age 26.4, SD 4.7 years) who had undergone bilateral sagittal split ramus osteotomy were selected, with a median follow-up of 8 months between pre- and postsurgical evaluation. Pre- and postsurgical cephalograms and lateral photograms were traced and changes were recorded.

Results: Pre- and postsurgical measurements of hard tissue angles and distances revealed higher correlations with cephalometrically performed soft tissue measurements of facial convexity (Class II: N-PG, $\mathrm{r}=-0.50, \mathrm{P}=0.047$; Class III: $\mathrm{ANB}, \mathrm{r}=0.73, \mathrm{P}=0.005 ; \mathrm{NaPg}, \mathrm{r}=0.71, \mathrm{P}=0.007 ;$ ) and labiomental angle (Class II: $\mathrm{SNB}, \mathrm{r}=0.72, \mathrm{P}=0.002 ; \mathrm{ANB}$, $\mathrm{r}=-0.72, \mathrm{P}=0.002 ; \mathrm{N}-\mathrm{B}, \mathrm{r}=-0.68, \mathrm{P}=0.004$; ANS-Gn, $\mathrm{r}=0.71, \mathrm{P}=0.002$; Class III: ANS-Gn, $\mathrm{r}=0.65, \mathrm{P}=0.043$ ) compared with two-dimensional photogrammetry. However, two-dimensional photogrammetry revealed higher correlation between lower lip length and cephalometrically assessed angular hard tissue changes (Class II: $\mathrm{SNB}, \mathrm{r}=0.98, \mathrm{P}=0.007$; $\mathrm{N}-\mathrm{B}, \mathrm{r}=0.89, \mathrm{P}=0.037 ; \mathrm{N}-\mathrm{Pg}, \mathrm{r}=0.90, \mathrm{P}=0.033$; Class III: SNB, $\mathrm{r}=-0.54, \mathrm{P}=0.060 ; \mathrm{NAPg}, \mathrm{r}=-0.65, \mathrm{P}=0.041 ; \mathrm{N}-\mathrm{Pg}$, $\mathrm{r}=0.58, \mathrm{P}=0.039)$.

Conclusions: Our findings suggest that cephalometry and two-dimensional photogrammetry offer the possibility to complement one another.
\end{abstract}

Keywords: cephalometry; photogrammetry; orthognathic surgery; mandibular advancement; osteotomy.

\section{Accepted for publication: 11 July 2011}

To cite this article:

Vandeweghe Rustemeyer J, Martin A. Assessment of Soft Tissue Changes by Cephalometry and Two-Dimensional Photogrammetry in Bilateral Sagittal Split Ramus Osteotomy Cases.

J Oral Maxillofac Res 2011 (Jul-Sep);2(3):e2

URL: http://www.ejomr.org/JOMR/archives/2011/3/e2/v2n3e2ht.pdf

doi: $10.5037 /$ jomr.2011.2302 


\section{INTRODUCTION}

Orthognathic surgery patients have been focusing more and more on postsurgical facial aesthetic outcomes. Findings in the recent literature suggest that aesthetic improvement is one of the most relevant motivations besides chewing function for patients undergoing orthognathic surgery $[1,2]$. However, the motives of patients for treatment are often not necessarily related to professionally determined needs and the increased focus on the aesthetic outcome may lead to a lowering of the threshold for surgery. This observation is supported by the fact that current orthodontic surgical patients exhibit smaller deviations from the norm than those treated 20 years earlier [3]. As a consequence, prediction methods for facial profile changes have become increasingly sophisticated and planning with soft-to-hard tissue movement ratios are now mandatory. However, ratios given in the literature could vary $[4,5]$ and, with respect to vertical movements, predicting soft tissue changes are difficult [6]. Hence, questions could be raised whether these variations are significant in a way that new techniques beyond standard techniques for predicting facial changes are needed. Is there really a necessity to develop additional methods for planning orthognathic surgery cases, and making them part of the routine, despite the fact that, on average, postoperative aesthetic outcomes are good? [2]]. Cephalometry and two-dimensional photogrammetry have been more advantageous with regard to high patient comfort, portability, costs, and accessibility, compared with three-dimensional photogrammetry. However, the disadvantages of the standard techniques are the lower statistical accuracy, including greater standard deviations, and the comparative difficulty of reaching landmarks [7]. Against this recent background, we aimed to compare the soft tissue profile assessed by lateral cephalograms and two-dimensional photogrammetry in the present study.

\section{MATERIAL AND METHODS}

\section{Subject sample}

Subjects who had undergone single jaw surgery for Class II or Class III relationship were selected from adult treatment records. Exclusion criteria were: patients who revealed an frontal open bite, adiposity (Body Mass Index $\left.(B M I)>30 \mathrm{~kg} / \mathrm{m}^{2}\right)$, patients with matured cleft lip and palate, craniofacial syndromes, post-traumatic deformity, and patients who were scheduled to undergo orthognathic surgery without orthodontic treatment or with additional features, e.g. genioplasty or distractor devices. Therefore, orthognathic surgery consisted purely of bilateral sagittal split ramus osteotomy (BSSRO) carried out for mandibular setback or advancement. All subjects had available both a lateral cephalogram and a lateral photogram in the Natural Head Position (NHP) taken pre and postsurgical.

\section{Lateral cephalometry}

Subjects were positioned in the cephalostat, and then the head holder was adjusted until the ear rods could be positioned into the ears without moving the patient. All radiographs were taken with teeth together in centric occlusion and lips in repose, and with a metric ruler in front of the midfacial vertical line (NHP). No occipital supplement was used. According to the standard of cephalograms, the film distance to the X-ray tube was fixed at $150 \mathrm{~cm}$, and the film distance to the midsagittal plane of the patient's head at $18 \mathrm{~cm}$.

Tracings were done for all cephalograms. After transferring into a PC, the ruler helped adjust the size of the cephalograms in the software program so that $1 \mathrm{~mm}$ on the rule represented $1 \mathrm{~mm}$ of actual scale (life-size) in the Photoshop software program. The landmarks were identified manually by a single examiner using photographic software (Adobe Photoshop version 7.0, Adobe Systems, San Jose, CA, USA). Soft and hard tissue landmarks of the cephalograms were traced using a modified version [5] of the analysis of Legan and Burstone [ $\underline{8}]$ and Lew et al. [9] (Figure 1 and 2). Therefore, the horizontal reference line was constructed by raising a line $7^{\circ}$ from sella-nasion, and a line perpendicular to this at nasion was used as the vertical reference line. Movement of hard and soft tissue landmarks from pre- to postsurgery were measured in millimetres to the horizontal and vertical reference lines. The according angles were constructed and measured in angular degrees in the presurgical and postsurgical cephalograms. Differences were recorded as the surgical change.

\section{Two-dimensional photogrammetry}

Subjects were asked to sit on a chair in front of a pale blue background, maintain a straight back, and look straight ahead with a relaxed facial expression and eyes fully open, lips gently closed, and not smiling. A neck holder was then adjusted to help the subjects fix their position in NHP. For reproducibility, a simple, indirect light source on the ceiling was used, consisting of four 60-watt fluorescent tubes to eliminate undesirable shadows from the contours of the facial profile. The subjects' faces were photographed in right lateral 


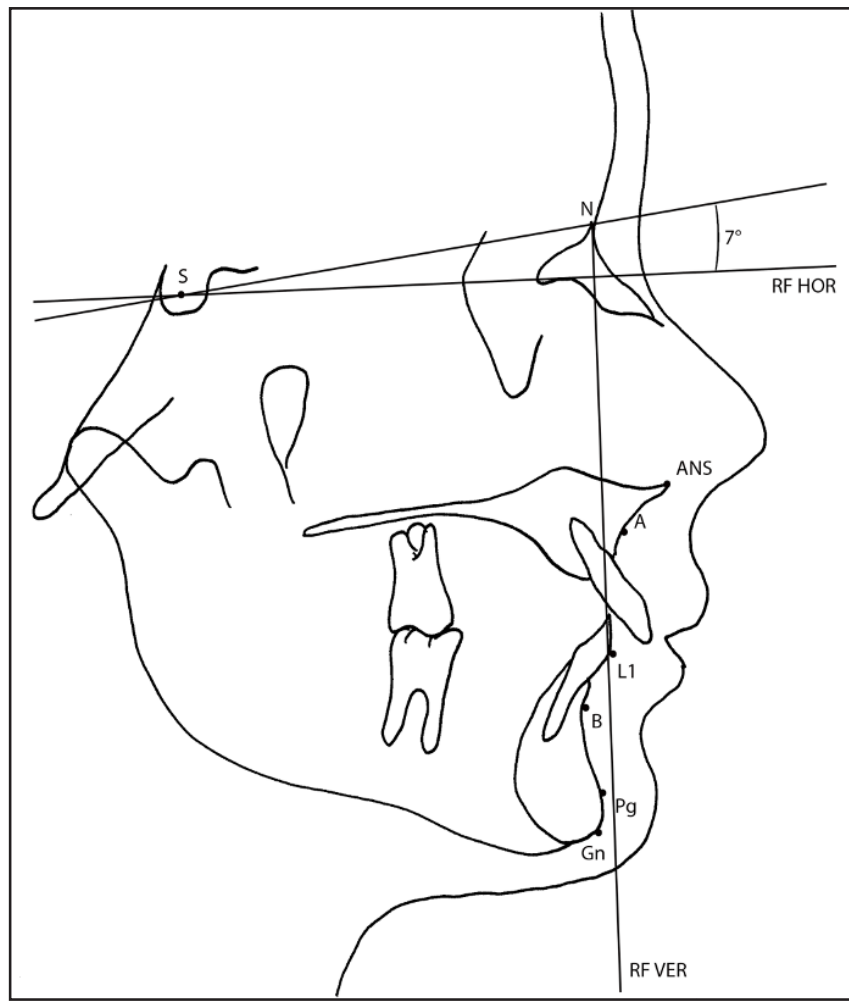

Figure 1. Hard tissue landmarks and reference lines for tracing of cephalograms: $\mathrm{N}=$ Nasion; $\mathrm{S}=$ Sella; $\mathrm{A}=$ Point $\mathrm{A}$; $\mathrm{B}=$ Point B; L1 = Lower incisor; $\mathrm{Gn}=$ Gnathion; $\mathrm{Pg}=$ Pogonium; $\mathrm{ANS}=$ Anterior nasal spine; RF HOR $=$ Horizontal reference line; $\mathrm{RF}$ VER $=$ Vertical reference line.

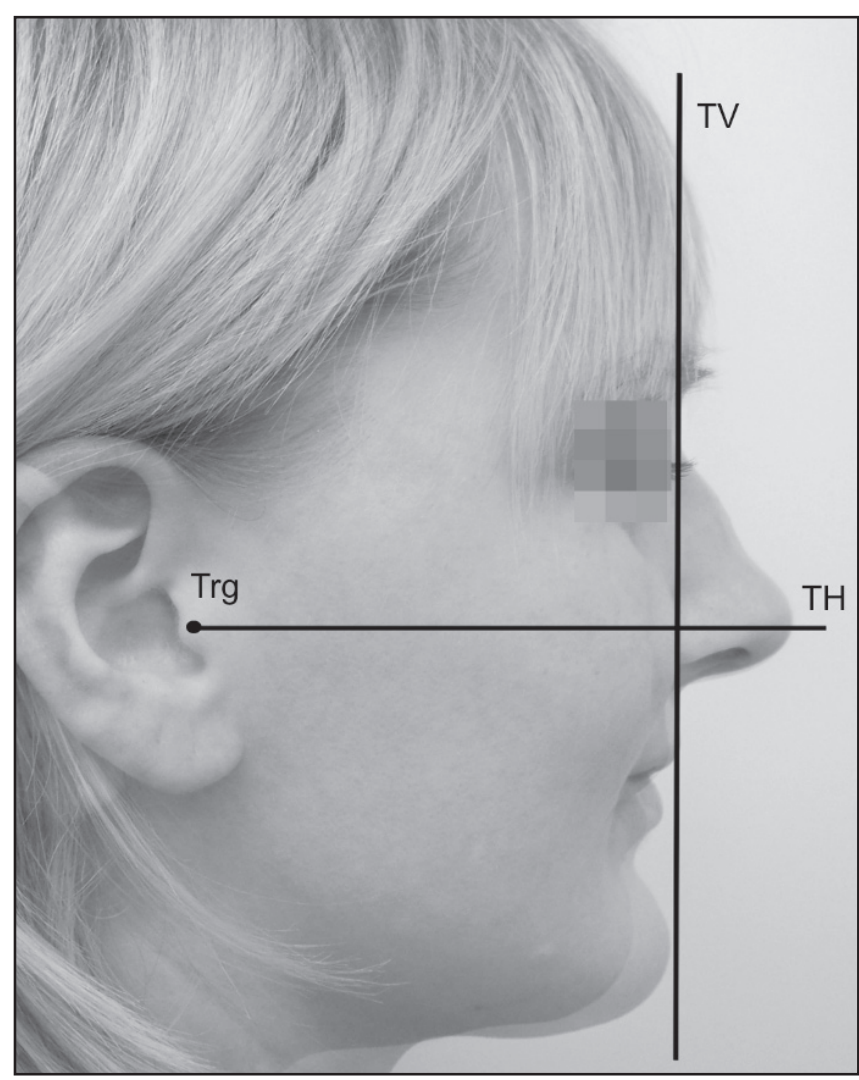

Figure 3. Superimposed lateral photograms to assess pre- and postsurgical soft tissue landmark movements: $\mathrm{TV}=$ True Vertical in Nasion; $\mathrm{TH}=$ True Horizontal; $\operatorname{Trg}=$ Tragus .

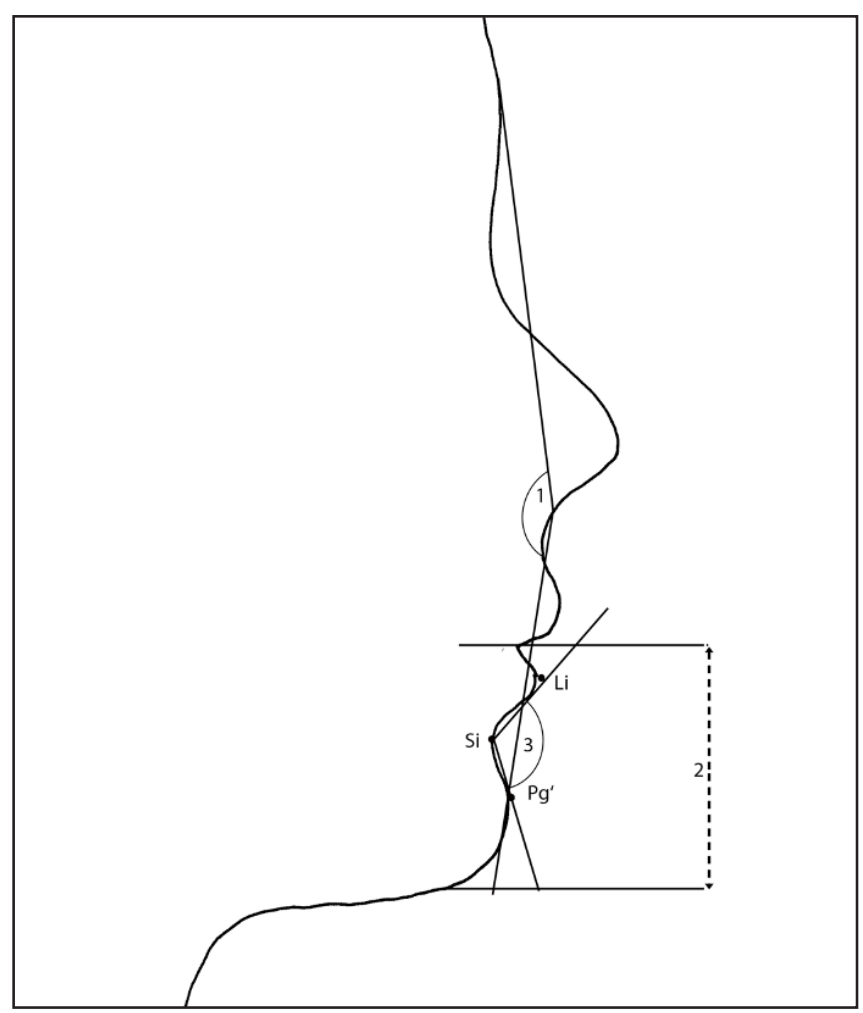

Figure 2. Soft tissue landmarks, angles and distances for tracing cephalograms and photograms: $\mathrm{Li}=$ Labrale inferius; $\mathrm{Si}=$ Labiomental sulcus; $\mathrm{Pg}^{\prime}=\mathrm{Soft}$ tissue pogonion; $1=$ Facial Convexity; 2 = Lower lip length; 3 = Labiomental angle.

view, together with a metric scaled ruler in front of the midfacial vertical line (True Vertical [TV]). A highresolution digital camera with a flash (Canon 450D, Tokyo, Japan) was firmly mounted on a photo stand 1 $\mathrm{m}$ in front of the subject. All photographs were taken at $2.048 \times 1.536$ pixels resolution and saved in JPEG file format. Images were stored on the PC's hard disc drive and then transferred into the photographic software program. The lateral photographs were adjusted to lifesize in accordance to the adjustment of the cephalograms given above. Soft tissue landmarks, distances and angles were traced with the tools of the software (Figure 2). TV in nasion and the True Horizontal $\mathrm{TH}$, perpendicular to TV through tragus) were constructed as reference lines for horizontal and vertical landmark movements. To assess pre- to postsurgical soft tissue landmark movements, photograms were superimposed achieving congruence in the reference lines. Pre- to postsurgical distances of each landmark towards reference lines were measured and recorded as the vertical and horizontal surgical change, respectively (Figure 3 ).

\section{Statistical analysis and method error calculation}

The collected data were subjected to statistical analysis using the PASW statistical software package, version 18.0 (SPSS, Chicago, IL, USA). Differences between 
groups were evaluated using the paired $\mathrm{t}$ - test. Results were considered significant if $\mathrm{P}<0.05$ and highly significant if $\mathrm{P}<0.01$. Pearson`s correlation analysis was used to assess the degree of correlation between soft and hard tissue changes. Reliability of measurements was determined by randomly selecting 10 cephalograms and 10 lateral photograms to repeat the tracings by a second senior examiner. No significant differences were found when the repeat measurements were evaluated with t-test. The inter-rater correlation (Pearson's correlation) of data determined by the investigators was 0.94 for cephalometric and 0.95 for photogrammetric tracings. The method error was calculated using the formula $\sqrt{\sum\left(\mathrm{X}_{1}-\mathrm{X}_{2}\right)^{2}} / 2 \mathrm{n}$ in which $\mathrm{X}_{1}$ as the first measurement, $\mathrm{X}_{2}$ as the second measurement, and $\mathrm{n}$ as the number of repeated records. Significant differences between the reliability of two-dimensional photogrammetry and cephalometry could not been obtained. All respective values of method error calculation for the linear measurements ranged between 0.23 and 0.36 $\mathrm{mm}$ for cephalometry and between 0.25 and 0.39 for two-dimensional photogrammetry, for angular measurements between 1.2 and 4.2 degrees and between 1.4 and 3.9 degrees, respectively. Hence, significant differences between the reliability of photogrammetry and cephalometry could not been obtained.

\section{RESULTS}

\section{Subject sample}

Study sample consisted of 49 white Caucasian subjects. Twenty-six patients with Class II relationship (mean age 25.5; standard deviation [SD] 5.2 years; female $\mathrm{n}=16$, male $\mathrm{n}=10$ ), and 23 patients with Class III relationship (mean age 26.4; SD 4.7 years; female $n=15$, male $n=8$ ) were selected with a median follow-up of 8 months (mean 8.3; SD 1.2 months) between pre- and postsurgical evaluation. Significant differences between females and males could not be obtained by cephalometric or two-dimensional photogrammetric measurements, with respect to pre- or postoperative angular or distance measurements, or landmark movements. Therefore, gender was not considered further.

\section{Pre- and postsurgical evaluation of angle and distances}

Significant differences between pre- and postsurgical parameters could be found for all hard tissue measurements exceptional for ANS-Gn in Class III patients (Table 1). Pre- and postsurgical soft tissue measurements of facial convexity were cephalometrically and photogrammetrically significantly different in Class II $(\mathrm{P}<0.001$, $\mathrm{P}=0.002$, respectively) as well as in Class III patients $(\mathrm{P}<0.001, \mathrm{P}=0.003)$, whereas only in Class II patients significant differences in labiomental angle measurements could be obtained $(\mathrm{P}<0.001$, $P=0.044)$. Significant differences between the lengths of the lower lip could be found neither cephalometrically nor photogrammetrically in Class II or III subjects. Pre- and postsurgical changes of angles or distances between Class II and III patients revealed no significant differences.

Significant correlations between soft and hard tissue changes for angles and distances could be found mostly for cephalometric soft tissue measurements of facial convexity and labiomental angle (Table 2). For Class II patients, more significant correlations occurred cephalometrically. Especially between labiomental angle and hard tissue measurement of SNB $(\mathrm{P}=0.002), \mathrm{N}-\mathrm{B}(\mathrm{P}=0.004)$ and ANS-Gn $(\mathrm{P}=0.002) \mathrm{SNB}, \mathrm{N}-\mathrm{B}(\mathrm{P}<0.01)$ and ANS-Gn correlations were of high significance. On the other hand, the lower lip length showed less significant correlations to hard tissue parameters. In contrast, with two-dimensional photogrammetry, the most significant correlations could be found between the lower lip length and cephalometrically assessed hard tissue parameters in Class II and III patients. However, Class II and III patients revealed significant correlations for different hard tissue parameters. No significant correlation could be obtained between photogrammetrically determined facial convexity and cephalometrically assessed hard tissue measurements. For labiomental angle measurements, a significant correlation towards ANB measurements was found only for Class III patients $(\mathrm{P}=0.048)$.

\section{Pre- to postsurgical movement of landmarks}

Significant differences between two-dimensional photogrammetric and cephalometric assessment of soft tissue landmark movements in Class II and III patients could be obtained neither in horizontal nor in vertical direction (Table 3). The comparison between movements of landmarks in horizontal and vertical direction revealed that horizontal movements were of greater amount for each landmark.

\section{DISCUSSION}

The results of this study supported the findings in other studies in that mandibular movements with 
Table 1. Differences between pre- and postsurgical parameters for class II and III patients

\begin{tabular}{|c|c|c|c|c|c|c|c|}
\hline & \multirow{2}{*}{ Parameter } & \multirow{2}{*}{ Class } & \multirow{2}{*}{$\begin{array}{l}\text { Presurgery } \\
\text { Mean } \pm \text { SD }\end{array}$} & \multirow{2}{*}{$\begin{array}{c}\text { Postsurgery } \\
\text { Mean } \pm \text { SD }\end{array}$} & \multirow{2}{*}{$\begin{array}{c}\text { Difference } \\
\text { Mean } \pm \text { SD }\end{array}$} & \multicolumn{2}{|c|}{ t- test } \\
\hline & & & & & & $\mathbf{P}^{\mathbf{a}}$ & $\mathbf{P}^{\mathbf{b}}$ \\
\hline \multirow{12}{*}{$\begin{array}{l}\text { Cephalometry } \\
\text { (hard tissue) }\end{array}$} & \multirow{2}{*}{ SNB $\left(^{\circ}\right)$} & II & $75.5 \pm 3.8$ & $77.7 \pm 4.2$ & $-2.2 \pm 1.8$ & $<0.001^{\mathrm{d}}$ & \multirow{2}{*}{0.939} \\
\hline & & III & $82.1 \pm 5.9$ & $79.7 \pm 5.3$ & $2.3 \pm 2.2$ & $0.003^{\mathrm{d}}$ & \\
\hline & \multirow{2}{*}{ ANB $\left(^{\circ}\right)$} & II & $4.9 \pm 3.5$ & $2.5 \pm 3.3$ & $2.4 \pm 1.5$ & $<0.001^{\mathrm{d}}$ & \multirow{2}{*}{0.841} \\
\hline & & III & $-0.1 \pm 2.5$ & $2.0 \pm 3.3$ & $-2.2 \pm 1.6$ & $<0.001^{\mathrm{d}}$ & \\
\hline & \multirow{2}{*}{ NAPg $\left(^{\circ}\right)$} & II & $-6.7 \pm 8.6$ & $-3.1 \pm 8.2$ & $-3.6 \pm 4.5$ & $0.006^{\mathrm{d}}$ & \multirow{2}{*}{0.898} \\
\hline & & III & $1.2 \pm 6.1$ & $-2.6 \pm 7.4$ & $3.8 \pm 3.2$ & $<0.001^{\mathrm{d}}$ & \\
\hline & \multirow{2}{*}{ N-B (mm) } & II & $7.7 \pm 3.4$ & $5.9 \pm 4.0$ & $1.8 \pm 1.7$ & $<0.001^{\mathrm{d}}$ & \multirow{2}{*}{0.370} \\
\hline & & III & $1.1 \pm 6.3$ & $3.6 \pm 5.8$ & $-2.5 \pm 2.8$ & $0.007^{\mathrm{d}}$ & \\
\hline & \multirow{2}{*}{ N-Pg (mm) } & II & $6.6 \pm 4.8$ & $5.1 \pm 5.2$ & $1.5 \pm 1.6$ & $0.002^{\mathrm{d}}$ & \multirow{2}{*}{0.124} \\
\hline & & III & $0.4 \pm 7.3$ & $3.3 \pm 6.8$ & $-2.9 \pm 3.2$ & $0.006^{\mathrm{d}}$ & \\
\hline & \multirow{2}{*}{ ANS-Gn (mm) } & II & $36.4 \pm 3.4$ & $37.1 \pm 2.7$ & $-1.1 \pm 2.1$ & $0.044^{\mathrm{c}}$ & \multirow{2}{*}{0.467} \\
\hline & & III & $40.7 \pm 4.1$ & $40.1 \pm 4.8$ & $0.6 \pm 1.8$ & 0.203 & \\
\hline \multirow{6}{*}{$\begin{array}{l}\text { Cephalometry } \\
\text { (soft tissue) }\end{array}$} & \multirow{2}{*}{ Facial convexity $\left(^{\circ}\right)$} & II & $163.6 \pm 6.3$ & $167.7 \pm 6.4$ & $-4.1 \pm 4.2$ & $<0.001^{\mathrm{d}}$ & \multirow{2}{*}{0.818} \\
\hline & & III & $173.9 \pm 4.8$ & $169.6 \pm 6.9$ & $4.3 \pm 3.5$ & $<0.001^{\mathrm{d}}$ & \\
\hline & \multirow{2}{*}{ Labiomental angle $\left(^{\circ}\right)$} & II & $86.6 \pm 28.7$ & $109.1 \pm 14.4$ & $-22.3 \pm 22.7$ & $<0.001^{\mathrm{d}}$ & \multirow{2}{*}{0.051} \\
\hline & & III & $129.7 \pm 11.6$ & $124.1 \pm 16.7$ & $5.6 \pm 13.1$ & 0.143 & \\
\hline & \multirow{2}{*}{ Lower lip length (mm) } & II & $24.7 \pm 2.9$ & $25.6 \pm 3.1$ & $-0.8 \pm 2.6$ & 0.201 & \multirow{2}{*}{0.254} \\
\hline & & III & $29.2 \pm 2.1$ & $28.7 \pm 2.9$ & $0.1 \pm 2.1$ & 0.388 & \\
\hline \multirow{6}{*}{ Photogrammetry } & \multirow{2}{*}{ Facial convexity $\left({ }^{\circ}\right)$} & II & $166.5 \pm 6.1$ & $160.5 \pm 4.9$ & $5.9 \pm 7.1$ & $0.002^{\mathrm{d}}$ & \multirow{2}{*}{0.614} \\
\hline & & III & $174.8 \pm 5.6$ & $163.8 \pm 5.4$ & $10.5 \pm 49.5$ & $0.003^{\mathrm{d}}$ & \\
\hline & \multirow{2}{*}{ Labiomental angle $\left(^{\circ}\right)$} & II & $102.2 \pm 19.3$ & $112.1 \pm 15.8$ & $-10.1 \pm 15.9$ & $0.044^{\mathrm{c}}$ & \multirow{2}{*}{0.857} \\
\hline & & III & $129.9 \pm 16.2$ & $120.6 \pm 11.9$ & $10.6 \pm 19.3$ & 0.959 & \\
\hline & \multirow{2}{*}{ Lower lip length (mm) } & II & $24.7 \pm 2.9$ & $25.6 \pm 3.1$ & $-0.8 \pm 2.6$ & 0.201 & 0023 \\
\hline & & III & $29.4 \pm 2.7$ & $28.9 \pm 2.3$ & $1.7 \pm 8.5$ & 0.448 & 0.933 \\
\hline
\end{tabular}

aP refers to pre- and postsurgical differences (t-test).

${ }^{\mathrm{b}} \mathrm{P}$ refers to differences in pre- and postsurgical changes between Class II and III patients (t-test).

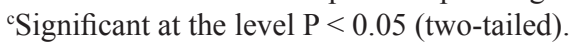

dSignificant at the level $\mathrm{P}<0.01$ (two-tailed).

BSSRO were effective on soft tissues both in vertical and horizontal directions $[\underline{5}, \underline{9}]$. Mandibular single-jaw surgery improved the facial convexity, labiomental angle, and lower lip lengths to approximate aesthetic norms. Arnett and Bergman $[\underline{10}, \underline{11}]$ described the facial profile according to the angle of the facial convexity in Class I (165 - 175 degrees), Class II ( $<165$ degrees), and Class III profiles ( $>175$ degrees). Following this classification, in this study postsurgical Class I facial convexity was achieved in Class II and III patients and could be assessed by two-dimensional photogrammetry as well as by cephalometry. However, cephalometrically and photogrammetrically changes of the labiomental angle could only be obtained in Class II patients. Fernández-Riveiro et al. [12] found that the labiomental angle should be evaluated with caution because of its high method error large variability (SD 9 - 11 degrees). In this study as well, photogrammetrically and cephalometrically defined labiomental angle measurements revealed the highest variability of all measurements.

Findings in this study suggest that cephalometry and two-dimensional photogrammetry offer the possibility to complement one another. Pre- and postsurgical measurements of hard tissue angles and distances revealed higher correlations with cephalometrically performed soft tissue measurements of facial convexity and labiomental angle than did two-dimensional photogrammetry. However, although higher correlations between hard and soft tissue cephalometry should be naturally explained by the fact that tracings for hard and soft tissue are performed on the same cephalogram, two-dimensional photogrammetry revealed higher correlations between the lower lip length and cephalometrically assessed angular hard tissue changes. In comparison, Marşan et al. [ㅁ] 
Table 2. Correlations between soft and hard ${ }^{a}$ tissue changes for angles and distances in Class II and Class III patients

\begin{tabular}{|c|c|c|c|c|c|c|c|c|c|}
\hline & Parameter & Class & & SNB & ANB & NAPg & N-B & $\mathrm{N}-\mathrm{Pg}$ & ANS-Gn \\
\hline \multirow{12}{*}{ Cephalometry } & \multirow{4}{*}{ Facial convexity $\left({ }^{\circ}\right)$} & \multirow{2}{*}{ II } & $\mathrm{r}$ & 0.45 & 0.63 & -0.06 & -0.28 & -0.50 & 0.32 \\
\hline & & & $\mathrm{P}$ & 0.083 & $0.035^{\mathrm{b}}$ & 0.825 & 0.298 & $0.047^{\mathrm{b}}$ & 0.224 \\
\hline & & \multirow{2}{*}{ III } & $\mathrm{r}$ & -0.31 & 0.73 & 0.71 & -0.27 & -0.19 & -0.38 \\
\hline & & & $\mathrm{P}$ & 0.302 & $0.005^{\mathrm{c}}$ & $0.007^{\mathrm{c}}$ & 0.370 & 0.525 & 0.203 \\
\hline & \multirow{4}{*}{ Labiomental angle $\left(^{\circ}\right)$} & \multirow{2}{*}{ II } & $\mathrm{r}$ & 0.72 & -0.72 & -0.24 & -0.68 & -0.48 & 0.71 \\
\hline & & & $\mathrm{P}$ & $0.002^{\mathrm{c}}$ & $0.002^{\mathrm{c}}$ & 0.377 & $0.004^{\mathrm{c}}$ & 0.058 & $0,002^{\mathrm{c}}$ \\
\hline & & \multirow{2}{*}{ III } & $\mathrm{r}$ & -0.38 & 0.06 & -0.12 & 0.42 & 0.49 & 0.65 \\
\hline & & & $\mathrm{P}$ & 0.200 & 0.851 & 0.696 & 0.151 & 0.083 & $0.043^{b}$ \\
\hline & \multirow{4}{*}{ Lower lip length (mm) } & \multirow{2}{*}{ II } & $\mathrm{r}$ & 0.51 & -0.35 & -0.04 & -0.48 & -0.33 & 0.49 \\
\hline & & & $\mathrm{P}$ & $0.041^{\mathrm{b}}$ & 0.181 & 0.881 & 0.058 & 0,209 & 0.055 \\
\hline & & \multirow{2}{*}{ III } & $\mathrm{r}$ & 0.05 & 0.10 & -0.10 & 0.01 & 0.03 & 0.59 \\
\hline & & & $\mathrm{P}$ & 0.871 & 0.746 & 0.735 & 0.966 & 0.930 & $0.032^{\mathrm{b}}$ \\
\hline \multirow{12}{*}{ Photogrammetry } & \multirow{4}{*}{ Facial convexity $\left({ }^{\circ}\right)$} & \multirow{2}{*}{ II } & $\mathrm{r}$ & 0.11 & -0.11 & 0.25 & -0.13 & -0.13 & 0.08 \\
\hline & & & $\mathrm{P}$ & 0.680 & 0.693 & 0.354 & 0.627 & 0.633 & 0.762 \\
\hline & & \multirow{2}{*}{ III } & $\mathrm{r}$ & -0.09 & 0.15 & -0.30 & -0.05 & -0.04 & 0.33 \\
\hline & & & $\mathrm{P}$ & 0.773 & 0.633 & 0.321 & 0.877 & 0.891 & 0.269 \\
\hline & \multirow{4}{*}{ Labiomental angle $\left(^{\circ}\right)$} & \multirow{2}{*}{ II } & $\mathrm{r}$ & 0.11 & -0.23 & -0.24 & -0.17 & -0.15 & 0.25 \\
\hline & & & $\mathrm{P}$ & 0.685 & 0.396 & 0.366 & 0.539 & 0.576 & 0.357 \\
\hline & & \multirow{2}{*}{ III } & $\mathrm{r}$ & 0.33 & -0.56 & 0.52 & -0.26 & -0.25 & -0.26 \\
\hline & & & $\mathrm{P}$ & 0.264 & $0.048^{\mathrm{b}}$ & 0.068 & 0.389 & 0.420 & 0.398 \\
\hline & \multirow{4}{*}{ Lower lip length (mm) } & \multirow{2}{*}{ II } & $\mathrm{r}$ & 0.98 & -0.09 & 0.13 & 0.89 & 0.90 & -0.11 \\
\hline & & & $\mathrm{P}$ & $0.007^{\mathrm{c}}$ & 0.729 & 0.634 & $0.037^{\mathrm{b}}$ & $0.033^{b}$ & 0.673 \\
\hline & & \multirow{2}{*}{ III } & $\mathrm{r}$ & -0.54 & 0.25 & -0.65 & 0.49 & 0.58 & 0.13 \\
\hline & & & $\mathrm{P}$ & 0.060 & 0.405 & $0.041^{\mathrm{b}}$ & 0.089 & $0.039^{b}$ & 0.667 \\
\hline
\end{tabular}

${ }^{\mathrm{a} A l l}$ hard tissue parameters were assessed by cephalometry.

${ }^{\mathrm{b}}$ Significant at the level $\mathrm{p}<0.05$ (two-tailed).

'Significant at the level $\mathrm{p}<0.01$ (two-tailed).

$\mathrm{r}=$ Pearson`s correlation; $\mathrm{P}=$ significance.

Table 3. Comparison between pre- and postsurgical soft tissue landmark movements assessed by two-dimensional photogrammetry and cephalometry in Class II and III patients

\begin{tabular}{|c|c|c|c|c|c|}
\hline & & & Photogrammetry & Cephalometry & t-test \\
\hline Direction & Parameter & Class & $\begin{array}{c}\text { Movement } \\
\text { Mean } \pm \text { SD }(\mathrm{mm})\end{array}$ & $\begin{array}{c}\text { Movement } \\
\text { Mean } \pm \text { SD }(\mathrm{mm})\end{array}$ & $\begin{array}{c}P \\
\text { (two-tailed) }\end{array}$ \\
\hline \multirow{6}{*}{ Horizontal } & \multirow{2}{*}{$\mathrm{Li}$} & II & $2.1 \pm 1.2$ & $2.6 \pm 1.6$ & $0.537^{\mathrm{a}}$ \\
\hline & & III & $-3.2 \pm 1.6$ & $-4.6 \pm 1.9$ & $0.255^{\mathrm{a}}$ \\
\hline & \multirow{2}{*}{$\mathrm{Si}$} & II & $2.8 \pm 1.4$ & $4.6 \pm 1.1$ & $0.065^{\mathrm{a}}$ \\
\hline & & III & $-4.4 \pm 0.8$ & $-4 . \pm 2.3$ & $0.862^{\mathrm{a}}$ \\
\hline & \multirow{2}{*}{ Pg } & II & $2.8 \pm 1.1$ & $4.1 \pm 1.8$ & $0.258^{\mathrm{a}}$ \\
\hline & & III & $-4.2 \pm 1.7$ & $-3.8 \pm 2.9$ & $0.803^{\mathrm{a}}$ \\
\hline \multirow{6}{*}{ Vertical } & \multirow{2}{*}{$\mathrm{Li}$} & II & $0.2 \pm 0.8$ & $0.4 \pm 1.3$ & $0.785^{\mathrm{a}}$ \\
\hline & & III & $1.4 \pm 1.5$ & $1.8 \pm 0.8$ & $0.623^{\mathrm{a}}$ \\
\hline & \multirow{2}{*}{$\mathrm{Si}$} & II & $-0.8 \pm 0.8$ & $-1.6 \pm 0.5$ & $0.117^{\mathrm{a}}$ \\
\hline & & III & $2.4 \pm 1.1$ & $3.4 \pm 2.8$ & $0.491^{\mathrm{a}}$ \\
\hline & \multirow{2}{*}{$\mathrm{Pg}^{`}$} & II & $-0.2 \pm 1.6$ & $-1.2 \pm 2.2$ & $0.435^{\mathrm{a}}$ \\
\hline & & III & $2.2 \pm 1.3$ & $3.4 \pm 1.9$ & $0.291^{\mathrm{a}}$ \\
\hline
\end{tabular}

${ }^{a}$ No statistically significant difference (t-test). 
cephalometrically found in 25 Turkish Class III subjects moderately significant correlations between facial convexity and SNB $(-0.54, \mathrm{P}<0.01)$ in contrast to a not significant correlation in this study $(-0.31$, $\mathrm{P}=0.302)$. However, the correlation between facial convexity and ANB was significant higher in this study $(0.73, \mathrm{P}=0.005)$ than in the latter $(0.73, \mathrm{P}=0.005)$. As a hypothesis, this variation might be contributed to different soft tissue responses in Turkish and Caucasian patients and should be clarified by further studies.

This study showed cephalometrically and photogram metrically no differences between females and males. Fernández-Riveiro et al. [12] found sexual dimorphisms for angles of the upper face and nose, not for lower face exceptional the mandibular contour. Anic-Milosevic et al. [13] reported that almost all the vertical profile measurements were greater in males than females. This inconsistency may be contributed to a smaller cohort and focusing only on mandibular surgery in this study. However, vertical profile measurements should be subjected to particularly close scrutiny: the present study underlines the observation from Lin and Kerr [14] that soft to hard tissue landmark movements in vertical directions showed lesser changes compared with changes in horizontal directions. One reason for lower vertical landmark movements might be that vertical mandibular movements in our patients were only minimal since subjects with a frontal open bite were not included in this study. Hence, the measurement of vertical landmark movements is still ambiguous; on one hand it is mandatory for soft tissue prediction; on the other hand measurements range near by the method error level [6]. However, the results of this study showed that the initial occlusal relationship of patients plays an important role in the significance of correlations between soft and hard tissue changes, but a much inferior role with respect to the ratios of landmark movements, Method error calculation revealed a high reliability of cephalometric and two-dimensional photogrammetric measurements in this study. However, inaccuracies of cephalometry and photogrammetry are still to consider. Arnett and Gunson [15] gave explanations for these possible inaccuracies; the soft tissue covering the teeth and bone can vary so greatly that the dentoskeletal pattern may be inadequate to evaluate facial disharmony or with imbalance in the lip-tissue thickness, facial disharmonies can be observed in the absence of dentoskeletal disharmonies. In accordance, Michiels and Tourne [16] found in 27 untreated Class I patients that the variability in soft-tissue thickness and axial inclination of incisors is the greatest source of cranialbase cephalometric inaccuracy. They conclude that measurements involving cranial-base landmarks are inaccurate in defining the actual clinical profile with respect to the variability of soft tissue thickness. We approached this problem by excluding patients with adiposity in this study. However, cranial-base cephalometric inaccuracy and the variability of soft tissue thickness could explain the differences found in this study between the correlations of soft to hard tissue changes assessed by photogrammetry and cephalometry.

In recent studies computer-aided three-dimensional digitizers have been used to evaluate facial changes. These studies have suggested that measurements obtained by new technological equipment should be more reliable than the conventional cephalometry, especially with respect to tracings of cranial-base landmarks [17,18]. Tuncer et al. [19] found that three-dimensional images generated from CT scans can facilitate the diagnosis, treatment planning, and outcome evaluation of severe asymmetry cases, for example hemimandibular hyperplasia. However, further studies are warranted to prove in which cases the more complex three-dimensional planning tools are really necessary for routine cases in orthognathic surgery.

\section{CONCLUSIONS}

For bilateral sagittal split ramus osteotomy cases, cephalometry and two-dimensional photogrammetry are still practical and reliable tools offer the possibility to complement one another.

\section{ACKNOWLEDGMENTS AND DISCLOSURE STATEMENTS}

The authors report no conflicts of interest related to this study. The authors would like to thank Ilknur Tetik (B.A., School of Architecture, Bremen, Germany) for giving us technical support realizing two-dimensional photogrammetry. 


\section{REFERENCES}

1. Cunningham SJ, Hunt NP, Feinmann C. Perceptions of outcome following orthognathic surgery. Br J Oral Maxillofac Surg. 1996 Jun;34(3):210-3. [Medline: 8818252] [doi: 10.1016/S0266-4356(96)90271-5]

2. Rustemeyer J, Eke Z, Bremerich A. Perception of improvement after orthognathic surgery: the important variables affecting patient satisfaction. Oral Maxillofac Surg. 2010 Sep;14(3):155-62. [Medline: 20306101] [doi: 10.1007/s10006-010-0212-2] [FREE Full Text]

3. Papadopoulos MA, Lazaridou-Terzoudi T, Øland J, Athanasiou AE, Melsen B. Comparison of soft and hard tissue profiles of orthognathic surgery patients treated recently and 20 years earlier. Oral Surg Oral Med Oral Pathol Oral Radiol Endod. 2009 Jul;108(1):e8-13. [Medline: 19540447] [doi: 10.1016/j.tripleo.2009.03.025]

4. Ingervall B, Thüer U, Vuillemin T. Stability and effect on the soft tissue profile of mandibular setback with sagittal split osteotomy and rigid internal fixation. Int J Adult Orthodon Orthognath Surg. 1995;10(1):15-25. [Medline: 9081988]

5. Marşan G, Oztaş E, Kuvat SV, Cura N, Emekli U. Changes in soft tissue profile after mandibular setback surgery in Class III subjects. Int J Oral Maxillofac Surg. 2009 Mar;38(3):236-40. Epub 2009 Jan 18. [Medline: 19153028] [doi: 10.1016/j.ijom.2008.12.005]

6. Okudaira M, Kawamoto T, Ono T, Moriyama K. Soft-tissue changes in association with anterior maxillary osteotomy: a pilot study. Oral Maxillofac Surg. 2008 Sep;12(3):131-8. Epub 2008 Jul 16. [Medline: 18629553] [doi: 10.1007/s10006-008-0121-9]

7. Ozsoy U, Demirel BM, Yildirim FB, Tosun O, Sarikcioglu L. Method selection in craniofacial measurements: advantages and disadvantages of 3D digitization method. J Craniomaxillofac Surg. 2009 Jul;37(5):285-90. [Medline: 19179087] [doi: $10.1016 /$ j.jems.2008.12.005]

8. Legan HL, Burstone CJ. Soft tissue cephalometric analysis for orthognathic surgery. J Oral Surg. 1980 Oct;38(10):744-51. [Medline: 6932485]

9. Lew KK, Loh FC, Yeo JF, Loh HS. Evaluation of soft tissue profile following intraoral ramus osteotomy in Chinese adults with mandibular prognathism. Int J Adult Orthodon Orthognath Surg. 1990;5(3):189-97. [Medline: 2098455]

10. Arnett GW, Bergman RT. Facial keys to orthodontic diagnosis and treatment planning. Part I. Am J Orthod Dentofacial Orthop. 1993 Apr;103(4):299-312. [Medline: 8480695] [doi: 10.1016/0889-5406(93)70010-L]

11. Arnett GW, Bergman RT. Facial keys to orthodontic diagnosis and treatment planning. Part II. Am J Orthod Dentofacial Orthop. 1993 May;103(5):395-411. [Medline: 8480709] [doi: 10.1016/S0889-5406(05)81791-3]

12. Fernández-Riveiro P, Smyth-Chamosa E, Suárez-Quintanilla A, Suárez-Cunqueiro. Angular photogrammetric analysis of the soft tissue facial profile. Eur J Orthod. 2003 Aug;25(4):393-9. [Medline: 12938846] [FREE Full Text]

13. Anic-Milosevic S, Mestrovic S, Prlić A. Proportions in the upper lip- lower lip -chin area of the lower face as determined by photogrammetric method. J Craniomaxillofac Surg. 2010 Mar;38(2): 90-5. [Medline: 19447641] [doi: 10.1016/j.jcms.2009.03.013]

14. Lin SS, Kerr WJ. Soft and hard tissue changes in Class III patients treated by bimaxillary surgery. Eur J Orthod. 1998 Feb;20(1):25-33. [Medline: 9558762] [doi: 10.1093/ejo/20.1.25] [FREE Full Text]

15. Arnett GW, Gunson MJ. Drs. G. William Arnett and Michael J Gunson on esthetic treatment planning for orthognathic surgery. Interviewed by Dipak Chudasama. J Clin Orthod. 2010 Apr44(4):227-235. [Medline:20666237]

16. Michiels LY, Tourne LP. Nasion true vertical: A proposed method for testing the clinical validity of cephalometric measurements applied to a new cephalometric reference line. Int J Adult Orthod Orthog Surg. 1990 ;5(1):43-52. [Medline: 2373912]

17. Nagasaka S, Fujimura T, Segoshi K. Development of a non-radiographic cephalometric system. Eur J Orthod. 2003 Feb;25(1):77-85. [Medline: 12608727] [doi: 10.1093/ejo/25.1.77] [FREE Full Text]

18. Mommaerts MY, Moerenhout BA. Reliability of clinical measurements used in the determination of facial indices. J Craniomaxillofac Surg. 2008 Jul;36(5):279-84. [Medline: 18358735] [doi: 10.1016/j.jcms.2007.11.005]

19. Tuncer BB, Atac MS, Yüksel S. A case report comparing 3-D evaluation in the diagnosis and treatment planning of hemimandibular hyperplasie with conventional radiography. J Craniomaxillofac Surg. 2009 Sep;37(6):312-9. [Medline: 19289289] [doi: 10.1016/j.jcms.2009.01.004]

\section{To cite this article:}

Rustemeyer J, Martin A. Assessment of Soft Tissue Changes by Cephalometry and Two-Dimensional Photogrammetry in Bilateral Sagittal Split Ramus Osteotomy Cases.

J Oral Maxillofac Res 2011;2(3):e2

URL: http://www.ejomr.org/JOMR/archives/2011/3/e2/v2n3e2ht.pdf

doi: $10.5037 /$ jomr.2011.2302 
Copyright (C) Rustemeyer J, Martin A. Accepted for publication in the JOURNAL OF ORAL \& MAXILLOFACIAL RESEARCH (http://www.ejomr.org), 11 July 2011.

This is an open-access article, first published in the JOURNAL OF ORAL \& MAXILLOFACIAL RESEARCH, distributed under the terms of the Creative Commons Attribution-Noncommercial-No Derivative Works 3.0 Unported License, which permits unrestricted non-commercial use, distribution, and reproduction in any medium, provided the original work and is properly cited. The copyright, license information and link to the original publication on (http://www.ejomr.org) must be included. 